\title{
A critical history of British earthquakes
}

\author{
Roger M.W. Musson \\ British Geological Survey, Edinburgh, U.K.
}

\begin{abstract}
«The third form of Reflective History is the Critical ... It is not history itself that is here presented. We might more properly designate it as a History of History; a criticism of historical narratives and an investigation of their truth and credibility. Its peculiarity in point of fact and of intention, consists in the acuteness with which the writer extorts something from the records which was not in the matters recorded».
\end{abstract}

G.W.F. Hegel, The Philosophy of History (1837)

\begin{abstract}
This paper reviews the history of the study of historical British earthquakes. The publication of compendia of British earthquakes goes back as early as the late 16th Century. A boost to the study of earthquakes in Britain was given in the mid 18th Century as a result of two events occurring in London in 1750 (analogous to the general increase in earthquakes in Europe five years later after the 1755 Lisbon earthquake). The 19th Century saw a number of significant studies, culminating in the work of Davison, whose book-length catalogue was published finally in 1924. After that appears a gap, until interest in the subject was renewed in the mid 1970s. The expansion of the U.K. nuclear programme in the 1980s led to a series of large-scale investigations of historical British earthquakes, all based almost completely on primary historical data and conducted to high standards. The catalogue published by BGS in 1994 is a synthesis of these studies, and presents a parametric catalogue in which historical earthquakes are assessed from intensity data points based on primary source material. Since 1994, revisions to parameters have been minor and new events discovered have been restricted to a few small events.
\end{abstract}

Key words historical earthquakes - seismicity earthquake catalogues - United Kingdom

\section{Introduction}

This paper is not a study of the history of British earthquakes, which can be found in Musson (1994, 1996a, 2002). It is a study of the history of the history of British earthquakes, who wrote it, why and how.

Although Britain is not an area much subject to earthquakes (maximum observed magni-

Mailing address: Dr. Roger M.W. Musson, British Geological Survey, West Mains Road, Edinburgh EH9 3LA, U.K.; e-mail: rmwm@bgs.ac.uk tude $6 M_{L}$; an earthquake of $4.7 M_{L}$ has a return period of ten years) it is an area with a long recorded history; and a long intellectual history. This means that conditions for recording the occurrence of earthquakes in Britain have been relatively good throughout the last 1000 years or so, and particularly in the last 300 .

The fact that earthquakes are quite uncommon, and that many British people may go throughout their life without ever feeling one, also means that people are more likely to take note of weak shaking than would be the case in other countries. In discussions on earthquake intensity (for example, in context of the workshop meetings of the ESC Working Group «Macroseismic Scales», Grünthal, 1998) the opinion is sometimes expressed that intensity 2 is a useless measure because it is never record- 
ed in practice. This is absolutely not the case in the Britain. A notable example is the damaging Colchester earthquake of 1884. Because this event was so newsworthy, even at the extreme limit of the felt area people were anxious to recount their experiences so as to be part of the historic occasion (Musson et al., 1990).

An extreme case is the person in Scotland in 1841, who had a stone monument erected in his garden to record the occurrence of an earthquake that was only heard at his location (Musson, 1993).

In the survey that follows, a chronological approach will be adopted, starting with the earliest studies of historical earthquakes and continuing to the present day.

\section{The earliest studies of British earthquakes (pre 18th century)}

The first traceable catalogue of earthquakes published in Britain is that of Fleming (1580). On 6 April 1580 a large (about $5 \frac{3}{4} M_{L}$ ) earthquake occurred with epicentre in the Dover Straits, which caused considerable damage in England, France and the Low Countries, and a few deaths (Neilson et al., 1984a; Melville et al., 1996). It was strongly felt in London, where two children were killed by falling stones. Such was the impact of the event in the English capital, that a number of pamphlets were rushed to the press, describing the earthquake, and generally exhorting people to reform their ways, given this warning of God's displeasure (Ockenden, 1936). One of these was a lengthy treatise by Abraham Fleming, the full title of which reads «A Bright Burning Beacon, forewarning all wise Virgins to trim their lampes against the comming of the Bridegroome. Conteining A generall doctrine of sundrie signs and wonders, specially Earthquakes both particular and generall: A discourse of the end of this world: A commemoration of our late Earthquake, the 6. of April, about 6. of the clocke in the evening 1580. And a praier for the appeasing of Gods wrath and indignation» (Fleming, 1580).

The emphasis of this work is religious in nature. However, Chapter 12 is entitled «A contemplation of wonderfull accidents, and princi- pally of Earthquaks, as well particular as generall, which have happened in the realms of England, Ireland, and Scotland, from the time of K. William the Conquerour, to the reigne of our sovereigne Lady and gratious Queene Elizabeth, \& c». For those not familiar with English history, the «start» of it has often been dated to the Norman invasion of William I (William the Conqueror) in 1066, which marked an abrupt change in dynastic succession from the earlier Saxon kings.

The catalogue is presented in the form of free text, moving from one event to another, rather than as any sort of table. Because of the interest of this very early catalogue, it may be as well to list the events in full. The earthquakes mentioned are as follows:

- «Reign of Eugenius» - London.

- March 1077 - all England.

- 1084 - unspecified.

- 1165 - Ely, Norfolk, Suffolk.

- 1179 - Oxenhall, near Darlington.

- Monday the week before Easter 1185 - all England; damage at Lincoln.

- January-February 1199 - Scotland.

- 1222 - Warwickshire.

- 1247 - London.

- 1248 - Bath and Wells.

- 1250 - St Albans.

- 1266 - Ireland.

- 1274 - various places in England.

- 1275 - all England, damage at Glastonbury.

- 1382 - two earthquakes in various places, especially Kent.

- 1563 - Lincoln and Northampton.

- 6 April 1580 - London.

Of these, the first is probably mythical, and the 1179 event is not an earthquake. No sources are given, but it is clear that the entries are mostly derived from medieval chronicles, directly or indirectly. It is noteworthy that there is only one event between 1382 and 1580, when one might expect the author to be better informed about his own time than about the 13th century.

Fleming's failure to mention a large English earthquake in 1575 , only five years previously, is particularly surprising. His principal source would seem to be the general historical work of 
Holinshed (1577), hardly surprising when one finds Fleming listed as a contributor to the second edition of Holinshed et al. (1587). Holinshed is also more or less the only source (albeit secondary) known for the Scottish earthquakes of 1202, which Fleming misdates, and the most accessible source for the Irish earthquake of 1266 (which is confirmed by The Annals of Clyn and Dowling; Butler, 1849). The dating problem for the Scottish swarm, probably either at Comrie or the Ochil Hills, can be resolved here in passing, especially necessary since Musson (1994) follows Fleming and gives the wrong date. Holinshed (1577) gives a specific date of 1199 for other occurrences, then states that about three years later a papal legate visited Scotland, and the January following this, the earthquakes occurred. Fleming evidently just picked the date written in numerals in the margin. The visit of the papal legate can be dated from other sources to 1201, so the earthquakes happened in 1202.

Fleming's paragraphs are padded out with descriptions of damage which don't appear in any of the sources now available to us, and which were probably fanciful inventions of Fleming to embellish his tale.

Other early surveys of historical earthquakes occur within the context of wider compendiums, including either universal studies of earthquakes or general lists of wonders. Thus fourteen British earthquakes between 1085 and 1580 get a mention in Batman (1581), a work falling into the latter category. Some of these works are early examples of the world earthquake catalogue; Bonito (1691) is a famous example.

An interesting and little-known example is the work of Goad (1686), who compiled a list of earthquakes, including a number of British events between 1551 and 1682, in the interest of studying them from an astrological perspective.

Members of the Royal Society took an active interest in British earthquakes in the late 17 th century and 18th century, but the work produced in this context, while providing useful data on earthquakes of that period (e.g., Boyle 1666, Wallis 1666), did not involve studies of historical earthquakes.

\section{The 18 th century}

The situation in the 18th century is similar to the 17 th, with regard to anecdotal catalogues produced out of antiquarian interest rather than with scientific intent. In most cases these are accounts of world earthquakes, which nevertheless also include British events. A typical example is Burton (1734). The occurrence of an abnormal number of British earthquakes in the year 1750, including two in central London, gave a boost to this sort of production, five years before the great Lisbon earthquake had a similar effect in the rest of Europe. The short catalogue of Anon (1750) is exclusively concerned with British events, and the general study of Grey (1750) places English earthquakes in a separate appendix. There is no attempt at source criticism, and landslips are frequently mixed up with earthquakes. (The word earthquake was still being used for landslip occasionally in the early 19th century). However, many works of this period do attempt to explain earthquakes scientifically, rather than attributing them to Divine intervention.

One study that requires particular attention because of its impact on later studies is that of Short (1749). Thomas Short was a Derbyshire doctor with a strong interest in mineral waters; he was also interested in the possible link between epidemic diseases and the weather. $\mathrm{He}$ spent many years collecting data from chronicles and histories, and published his «General Chronological History of the Air, Weather, Seasons, Meteors \&c» in two thick volumes. The bulk of the text consists of a chronological compilation of accounts of plagues and epidemics, together with any sort of weather information relating to the same years, treating «weather» in the broadest possible sense. His objective, scientifically enough, was to look for any sort of correlation between one type of data and another.

However, at the back of the second volume appears a series of chronological tables for different phenomena, the first appearing being earthquakes, which presents a list of dates and places starting with an earthquake at Babylon in 2407 AM (Anno Mundi - in other words 1597 B.C.) and ending with a Sussex earthquake in 1734. (The second list is for comets, and there 
are further ones for floods, heavy snowfalls and some other less usually encountered phenomena). The striking thing about this table is that it contains numerous earthquakes from very early periods that appear nowhere else, for example, Dumbarton being «greatly shaken» in 12 A.D.; «terrible at Canterbury» in 193 A.D., and many more. These were duly transcribed by many later cataloguers of earthquakes, but it is impossible to imagine what sources Short could have drawn on for these data, and it is rather unlikely that Dumbarton even existed in 12 A.D. The other lists have similar problems, with a comet over London in 42 A.D., floods in Edinburgh in 155 A.D. (rather unlikely given early Edinburgh's hilltop location) and so on.

It is also notable that none of these dubious data appear in Short's main text, and where earthquakes do appear in the main text, they are referenced, and always genuine. A possible hypothesis is that some practical joker handed Short a list of fake events, and Short, while distrusting it too much to include it in his main text, nevertheless could bring himself to discard it entirely.

These spurious events have proved quite difficult to kill, partly because they were copied by so many other authors, including, for example, Milne (1911). Even as recently as Tiedemann (1991) the 1400 fatalities at St Andrews in the fake 811 A.D. earthquake reappear with a warning that British seismicity may be stronger than it appears; another legacy of Short's table.

\section{The 19th century}

The middle years of the 19th century were a period of great industry as regards historical research into earthquakes generally. The great catalogues of von Hoff (1840) and Mallet (18531855) are well known, as are the regional and annual catalogues of Perrey, who published his study of historical earthquakes in the British Isles in 1849. These catalogues are familiar to all in the field of historical seismology, and it is not necessary to discuss them further here.

Less well known is the work of David Milne (no relation to John Milne), later David MilneHome, whose work was influential on later British studies. Milne can fairly be stated to have been the first seismologist: he was involved in setting up a local instrumental network (in 1840-1841!), in conducting macroseismic surveys of recent events, in historical seismology, and in theoretical speculation. He also proposed the word «seismometer», from which all other «seismo-» words are back-formations. His theoretical ideas were in some respects quite advanced for his time; he wrote very well on the subject of focal depth, and was able to propose that the long axes of elliptical isoseismals should be aligned with major faults even though he had no idea of the causal relation between faults and earthquakes.

His historical catalogue (Milne, 1842) eschews the usual scrapings from the monastic chronicles via the likes of Holinshed (1577) and starts instead in 1608, running forward to 1839 , and then merging with contemporary observations from 1839 onwards. He gives sources where these are periodical publications such as Gentleman's Magazine or the Transactions of the Royal Society of Edinburgh, but many earthquakes are listed with dates and descriptions but no references. It seems to be the case that most of these are taken from newspaper data. This catalogue therefore rests on primary source data to a much greater extent than many catalogues of this period.

In compiling this catalogue, Milne made a number of dating errors that can often be traced back to newspaper practices. It was often the case that one weekly newspaper would publish a paragraph that would start «Extract of a letter from Ulverston - last Tuesday many people observed a smart shock of an earthquake ...». The editor of the weekly newspaper in a neighbouring town would see this item and copy it verbatim, without any acknowledgement, in the next issue of his newspaper. Someone finding only the second publication of the paragraph would miscalculate the date of the earthquake from the words «last Tuesday» taking the second publication date as reference. A number of times, Milne (1842) assigns dates to earthquakes that are one week later than the correct date, and sometimes the earthquake is duplicated and appears with both dates. Many later studies simply copied Milne's entries without checking, and replicated these errors. 
Two other individual catalogues from this period merit mention here.

Meldola and White (1885) compiled a remarkable book-length study of the damaging 1884 Colchester earthquake, and included a historical introduction, including a list of the more prominent British earthquakes to date. It relies mostly on Mallet (1852-1854), Short (1749) and some other secondary references. It would not be remarkable of itself, but it has been quoted a number of times by authors referring to this work for its account of the 1884 earthquake. It includes the memorable mistake of listing a damaging earthquake in Ireland in 1734; this can be traced back to a misreading of a reference to an earthquake in Iceland.

The catalogue of Roper (1889) is a pamphlet of 46 pages (including index) of earthquakes in the British Isles from the beginning of the Christian era up to 1889 . It is one of the fuller such works to appear, and is referenced throughout, but is based mostly on Short (1749), Milne (1842) and Mallet (1852-1854), with some information from other sources such as Gentleman's Magazine, and other periodicals including newspapers (usually the Lancaster Gazette, since Roper lived in or near Lancaster).

\section{Charles Davison}

Up to this point, all the catalogues discussed have been based on a process of compilation of historical data more or less without any critical scrutiny. This begins to change with the work of Davison, a mathematics teacher who, in 1889 , began to devote himself to the study of earthquakes as a hobby. From 1889 to 1926 (intermittently in the latter years) he conducted singlehandedly macroseismic surveys of British earthquakes, publishing the results in a long series of papers. He also published a number of books on various seismological subjects. He is best known, though, for his catalogue of British earthquakes, published in 1924 after 28 years of research. (The period of gestation is known because he printed an appeal for information about historical British earthquakes in several newspapers in 1896).

This catalogue (Davison, 1924) is a work of 416 pages, and includes a synopsis of the re- sults of his various investigations since 1889 , accounts of historical earthquakes back as far as he felt records were reliable (which is to 974 A.D.), and final sections of discussion on the distribution of British earthquakes in space and time, the causes of earthquakes, sound phenomena, and other topics.

The main section of the work is divided into chapters according to region, starting with the north of Scotland and moving south. Within each chapter, earthquakes are divided up according to originating «centres». Thus the chapter on earthquakes in South Wales has four sections: Pembroke earthquakes, Carmarthen earthquakes, Swansea earthquakes, and «earthquakes of unknown epicentres in South Wales». For each centre, events are listed in chronological order, distinguishing between events considered doubtful or uncertain, and those better attested. In fact, Davison is usually unduly pessimistic in which events he considers to be uncertain; in the majority of cases subsequent research has shown them to be genuine.

Earthquakes are assigned intensities where possible, using Davison's own modification of the Rossi-Forel Scale, better considered as a scale in its own right (Davison, 1900). The scale is unusual in having one test only for each degree, and is hard to correlate with other scales. For example, intensity 5 is defined simply as «the observer's seat was perceptibly moved or raised».

Felt areas are estimated by Davison wherever possible. This is therefore the first attempt at anything like a parametric catalogue of British earthquakes. However, he does not give epicentres as co-ordinate values, only the names of the nearest town. Approximate numerical epicentres could easily be reconstructed from this, however, and he does include a map, shown here as fig. 1.

Davison recognised the difficulties inherent in the chronology of the medieval earthquakes and that previous catalogues contained duplicates; however, his success in improving the situation was limited. He was the first author to recognise that the very early earthquakes listed in Short (1749) are all fakes, and also made an effort to eliminate other fake events, for instance, those due to landslips. He was therefore the first 


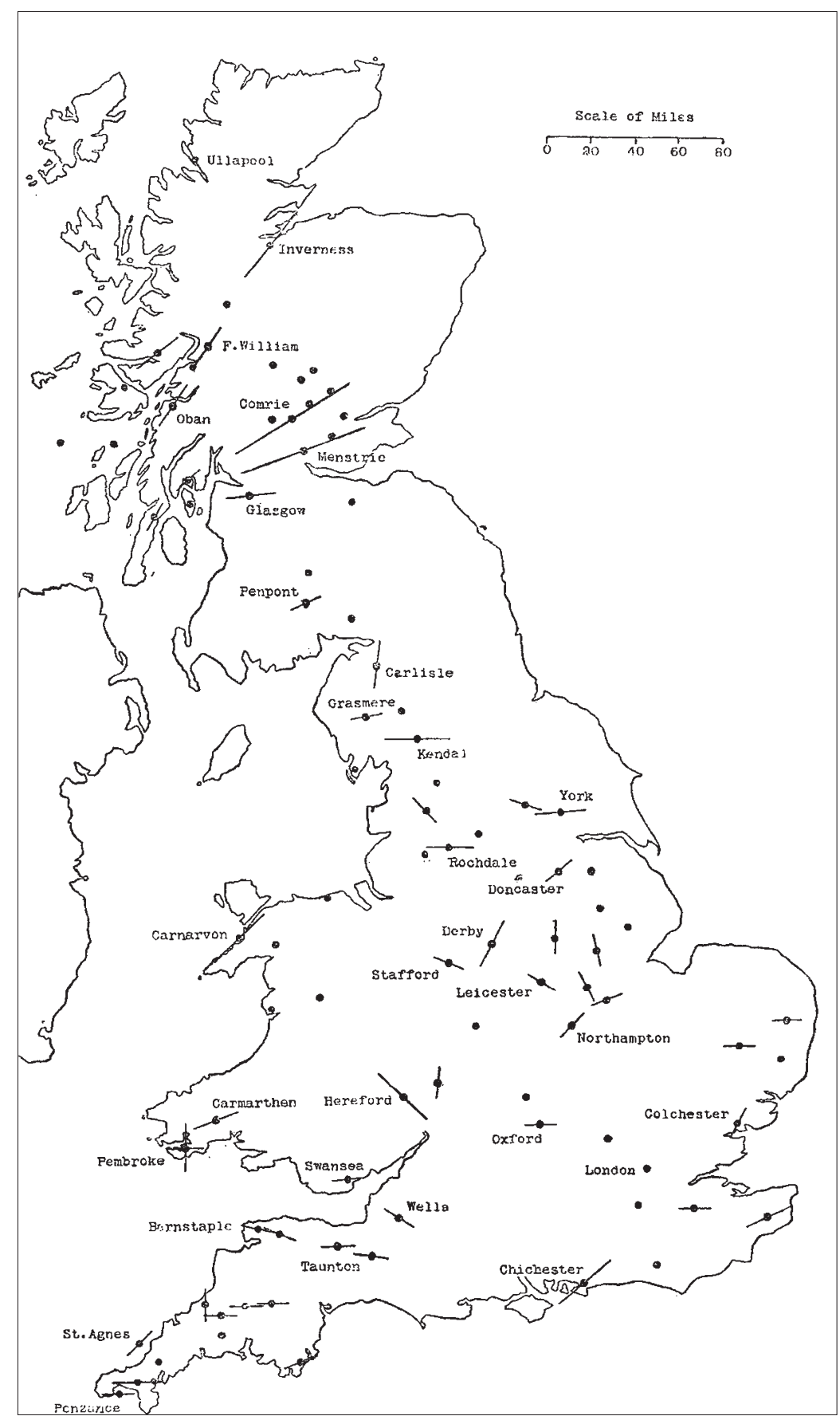

Fig. 1. Map of earthquake «centres» in the U.K., with estimated fault orientations, according to Davison (1924). 
historian of British earthquakes to make a clear attempt to apply critical standards to source material. However, working with limited resources and training, he still perpetuated a number of errors, such as dating errors in Milne (1842).

For many years this work remained the definitive account of historical British earthquakes. Davison's work of conducting macroseismic surveys of British earthquakes was continued by A.T.J. Dollar of the University of Glasgow (later of Birkbeck College, London). Dollar's record in publishing the results of his macroseismic surveys was much poorer than Davison's; however, at least the data collected by Dollar were preserved for posterity by his widow, unlike Davison's widow, who burnt all his papers after his death in 1941. Dollar (1950) published a catalogue of Scottish earthquakes 1916-1949, but did not engage in historical earthquake studies.

One researcher who did follow in Davison's footsteps for historical investigation was A.E. Mourant, a medical doctor and amateur seismologist. He compiled a history of earthquakes in the Channel Islands (Mourant, 1931) based on a variety of historical source material including primary and secondary works (especially Mallet). Each event is given a description, and a maximum intensity value (Davison Scale) and felt area where possible.

\section{Modern historical earthquake studies}

In the mid 1970s there was a reawakening of interest in historical earthquake studies both in the British Geological Survey (then the Institute of Geological Sciences, IGS) and at Imperial College, London (Ambraseys and Melville, 1983).

\subsection{Lilwall's catalogue}

One of the first products of this was the work of Lilwall (1976) who attempted to create a properly parametric catalogue of U.K. earthquakes for the first time. This was largely done by taking Davison's catalogue, assigning latitudes and longitudes to the various seismic «centres», and making some preliminary assumptions about magnitudes, including setting a default «mini- mum probable» magnitude for use where no other information existed. This was extended forwards in time by adding data from Dollar (1950) and Tillotson (1974). The report by Lilwall (1976) presents some analysis based on the preliminary version of the catalogue that never went beyond being a working file; it was not published in full by Lilwall because it was not regarded as a finished work. A copy of the file nevertheless fell into other hands, and was (as «the IGS file») subjected to a dissection it was not intended to bear (e.g., Soil Mechanics, 1982). This file also seems to be the basis for the listing of U.K. seismicity in Van Gils (1988). The file was published by Burton et al. (1984a) in order to provide a proper citable reference for the catalogue.

\subsection{The Inverness report}

A study of earthquakes in the vicinity of Inverness (Northern Scotland) by Browitt et al. (1976) seems to be the first published study in the U.K. in which historical earthquakes are revaluated from original source data. This study reproduces verbatim historical accounts from original newspaper descriptions, and assesses epicentral intensity values (MM and MSK), felt areas, and gives approximate magnitudes, but how these are derived is not discussed. The study makes the point that earthquakes in the mountainous north of Scotland have tended to «migrate» to settled regions; in other words, the population distribution affects the distribution of felt reports and this has caused misperceptions as to where the epicentres lay.

This study provides the first example in Britain of detailed historical work being undertaken to show that an event was a fake. This is the case of the 14 November 1769 Inverness earthquake, which supposedly threw down houses and killed several persons. This appears in various catalogues, including Davison (1924) and can be traced back to a single contemporary record in a periodical published in London (The London Magazine) in which the information is given on the authority of a letter from York. Browitt et al. (1976) examined specifically the Scottish sources that should have reported such an occurrence and found no local evidence that 
this earthquake ever occurred. Although no explanation has ever been found (one suggestion is that it relates to some other Inverness, perhaps in the Americas), all subsequent investigations of this earthquake have agreed with Browitt et al. (1976) conclusion that the event is fake.

\subsection{Principia Mechanica}

At the beginning of the 1980s a large expansion in historical earthquake studies occurred in the UK, in order to inform seismic hazard studies for the U.K. NPP programme. Three major studies were commissioned at the same time, from two consultancies, Principia Mechanica Ltd. and Soil Mechanics Ltd., and from BGS. A fourth study was completed in the same time frame (Ambraseys and Melville, 1983). These will be taken in turn.

The scope of the Principia (1982) study was ambitious - to produce a complete catalogue of historical British earthquakes from original sources, in one year. The final report consists of three volumes. The first contains a wide-ranging discussion of British seismicity including subjects such as magnitude calibration and attenuation of strong ground motion, concluding with a descriptive (rather than parametric) list of British earthquakes from the earliest times up to the 1970s (the list is deliberately incomplete for modern events). The remaining two volumes give detailed accounts of each earthquake. One volume deals with the 19th century (and selected earlier events), the other with the 20th century. For each earthquake a list of the sources used is given, some brief notes of maximum effects, maximum intensity (using a home-made scale of eight degrees), radius of felt area, and a map of data points. Larger earthquakes are also given isoseismal maps. Tables of Intensity Data Points (IDPs) are not given, and were not even made, the intensity values being entered directly onto the maps.

The amount of information processed in this study is impressive, although inevitably, in the attempt to do so much so quickly, mistakes were made in terms of under-rating some earthquakes, over-rating others, and failing to identify fake events. Many earthquakes receive cursory atten- tion. Numerical parameters are estimated only for some larger earthquakes, and not in the catalogue, but in a table in the text of the first volume.

\subsection{Soil Mechanics}

The study by Soil Mechanics (1982) was conducted in parallel to the Principia (1982) one. Rather than producing any catalogue, this study took a representative sample of 72 earthquakes from all parts of the U.K. and all time periods, and subjected each to a more thorough historical study, using more sources, than was possible within the scope of the Principia (1982) report. Intensities are assessed using the MSK scale, and magnitudes are estimated using seven different formulae taken from the literature. The parameters presented for the sample are quite detailed, including full sets of isoseismal radii, and depths. Depths are estimated using the Kövesligethy (1906) method (though other authors are referenced). Soil Mechanics counsel caution in handling macroseismic depth determinations; not surprising when their derived depth for the 1863 Hereford earthquake is $105 \mathrm{~km}$. The situation with regard to IDPs is no different to the Principia (1982) study.

\subsection{Burton, Musson and Neilson}

The BGS study that was conducted at the same time as Principia (1982) and Soil Mechanics (1982) was spread over three years instead of one, and published as Burton et al. (1984a). In outline it was similar to the study of Soil Mechanics in taking a sample of events; however, the sample was larger (102 against 72 ; one turned out to be a fake event) and contained most of the larger earthquakes after 1700.

This study was different in two important respects. First, the original source data on which intensity assessments were based were transcribed and reproduced verbatim, arranged by place. This means that the reports issued by this project contain the actual evidence of what occurred during each earthquake alongside the interpretations that are given in the form of intensity values. Secondly, the IDPs (MSK val- 
ues) for each earthquake are listed in full. This means that further analysis of the data collected by Burton et al. (1984a) is relatively easy, whereas for Principia (1982) and Soil Mechanics (1982) it is practically impossible.

Parameters other than epicentral intensity were not estimated for earthquakes in this study.

Owing to the sheer volume of the verbatim source material, the initial product of this study numbered fifteen volumes (Burton et al., 1984ab, Musson et al. 1984a-f; Neilson et al., 1984b,c). Further volumes, in more or less the same style, were issued in subsequent years, covering additional earthquakes (Musson et al., 1986a,b; Musson and Redmayne, 1986; Neilson et al., 1986; Musson, 1987, 1989a,b, 1991, 1998).

\subsection{Ambraseys and Melville}

The study by Ambraseys and Melville (1983) is concerned principally with earthquakes in the Eastern part of the U.K., and only with earthquakes before 1800. Parameters are not given, except for some $I_{\max }$ values and radius at which events were perceived at intensities between 3 and 4 MSK. IDPs are not listed. The important feature of this study is that it disentangled the complexities of dating of medieval earthquakes, and thus cleared up many of the fake earthquakes (from dating errors) from the earlier part of the U.K. catalogue once and for all.

\subsection{Other studies}

While the foregoing paragraphs encompass the major studies of historical earthquakes in the U.K. that were completed in the 1980s, a number of other noteworthy studies were also completed and/or published. All of these meet a high standard in use of primary source material and critical attention to sources. Some of these were conducted as part of NPP safety cases, were not published, and cannot be referred to.

Amongst published studies one may note Melville (1985), which discusses geographical factors affecting the transmission of historical earthquake data and gives a catalogue of 18th century earthquakes in England. Parameters include epicentral co-ordinates, $I_{\max }(\mathrm{MSK})$ and the radii of isoseismals 3 and 4 MSK. Melville (1986) presents descriptions for some NW England earthquakes. A study by Musson (1986) discusses in a general way the use of newspaper data for studies of historical British earthquakes.

Ambraseys (1985) includes intensity maps for some of the larger historical earthquakes in NW Europe (including the U.K.) and a parametric catalogue for 1800-1984, giving instrumental magnitudes (only), $I_{0}$ (MSK), depth and felt area. This was further developed in Ambraseys (1988) in which a parametric catalogue for the U.K. is presented for the period 1700-1984, for events with magnitude larger than $4.0 M_{s}$.

\subsection{Synthesis}

At the end of the 1980s, the situation with regard to the understanding of historical British earthquakes was completely transformed with respect to what it had been ten years before. The amount of data researched and published was now very large, and based almost entirely on primary historical source material. Earlier catalogues were used only as starting points for research.

What was now needed was synthesis of the data already uncovered in the form of complete numerate catalogues.

The first attempt at a synthetic catalogue was that of Ove Arup (1993), which draws on all the studies already listed, and also some unpublished investigations from site-specific safety cases by other authors. This study derives parameters (excluding depth) for events larger than $4 M_{s}$ since 1000 . Maximum intensities are given as MSK values, and areas for isoseismal 4 MSK are also listed. Some earthquakes below $4 M_{s}$ are included (down to $3.7 M_{s}$ ) and the total number of events is 106 .

A problem with this catalogue is that, in the drive to make it fully numerate, the authors proceeded to estimate parameters for some earthquakes on data so slender that no weight can be given to the results. One earthquake in the 11 th century is given a magnitude, an $I_{\max }$, 


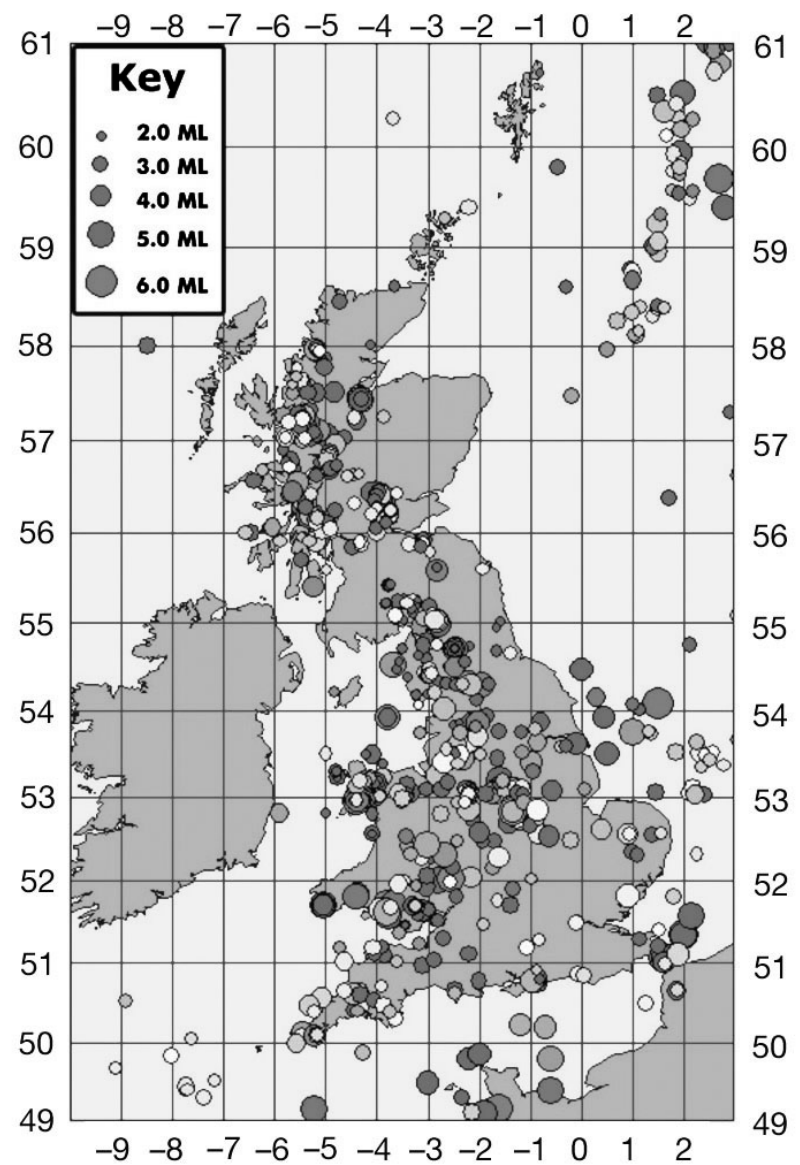

Fig. 2. Current U.K. seismicity map (historical and modern data combined). Symbol size is proportional to magnitude as shown in the key; shading is related to depth (where known), with shallower events having lighter shading. Events with very uncertain epicentres (most medieval earthquakes) are not plotted.

an area of isoseismal 4 , and an epicentre to five kilometres, when all that is known about it is the date and that it happened «in England» and was «great». The text states that these values are «VERY APPROXIMATE»; the problem is that it often happens that a parametric catalogue becomes separated from its accompanying text, and that someone will attempt to draw conclusions from these parameters regardless of the fact that the uncertainty is so high that the epicentre could be almost anywhere in England.
The second such catalogue is that of Musson (1994), which supplements the published studies listed above with archive data. It can be divided into sections as follows: for the period before 1700 only events considered to be larger than 4 $M_{L}$ are listed, and parameters are not estimated where these are very uncertain. After 1700 all events above $3 M_{L}$ are listed, and some events less than $3 M_{L}$ where these are particularly interesting. This extension to lower magnitudes means that this catalogue contains many more parametric data than the previous ones listed, 
and is thus better for purposes such as estimating magnitude recurrence. It also integrates with data from modern microseismic monitoring.

The derivation of parameters is described by Musson (1996b). Magnitudes are derived from analysis of felt area or outer isoseismals. Depths are estimated by the Kövesligethy (1906) method. Intensities are cited as EMS values. In some cases these are MSK values converted on the basis of one-to-one, sometimes with split values (e.g., 6-7 MSK) rounded down. The number of earthquakes in the catalogue is 502, including modern data.

The weaknesses of this catalogue are two in number. Firstly, more could be said about medieval and early earthquakes, the focus of the catalogue being really on the period after 1700 . In particular, the distinction between medieval events deemed to be probably above $4 \mathrm{M}_{L}$ (and therefore included) and those probably not (and therefore excluded) is rather subjective. Secondly, the documentation of sources, where entries are not derived wholly from published studies, leaves much to be desired. A report on source material for the BEECD project (Musson, 1996c) gives some improvement, but an expansion of Musson (1994) to include more detailed, referenced descriptions is still needed.

An unpublished extension of Musson (1994) includes data since 1994, revisions to historical parameters and historical earthquakes discovered since 1994, and also parameters for many historical earthquakes smaller than $3 M_{L}$. This version is integrated with the BGS earthquake database (Walker, 2000). The seismicity of the U.K., as shown in this combined historical and modern data set, is shown here as fig. 2. Following the BEECD project (Stucchi et al., 1999) a database of IDPs for almost all the major British earthquakes now exists. The idea was proposed some years ago that a comparative database of IDPs should be compiled, including intensity estimates made in the context of other historical studies made in the U.K.. However, it turned out that (as already mentioned), most of the other studies entered data points directly onto maps. The task of trying to construct tables of IDPs from maps is difficult and attempting it unrealistic; thus for the foreseeable future the only available IDPs are those from the various BGS studies.

\subsection{Outlook}

Further historical earthquake research in the U.K. is becoming a matter of diminishing returns. It is still possible to uncover reports of previously unknown earthquakes, but all those recently found have been small events, usually $3 M_{L}$ or less. A recent example can be given of the 1809 Cowbridge earthquakes, which turned up in the course of archive work in 2001.

These two earthquakes, on 15 July 1809 and 11 August 1809, are described in a collection of miscellaneous MSS in the National Library of Wales (MS reference 13121, ff 440, 453).

The second of the two was strong enough to cause the fall of plaster. The felt area is described in detail, is SW of Cardiff, and is about $230 \mathrm{~km}^{2}$ in size.

The prospect of major discoveries in historical British earthquake studies is very low, and the parametric record of British earthquakes seems to be as good as it is ever likely to be, thanks to the quantity and quality of historical research accomplished in the last 25 years.

\section{REFERENCES ( $\left(^{*}\right)$}

AMBRASEYS, N.N. (1985): Intensity-attenuation and magnitude-intensity relationships for northwest European earthquakes, Earthquakes Eng. Struct. Dyn., 13, 733-778.

Ambraseys, N.N. (1988): Engineering Seismology, Earthquakes Eng. Struct. Dyn., 17, 1-105.

Ambraseys, N.N. and C. Melville (1983): The Seismicity of the British Isles the North Sea (SERC Marine Technology Centre, London).

ANON (1750): Account of earthquakes in England, Gent. Mag., 20, p. 56.

Batman, S. (1581): The Doome, Warning All Men to the Judgemente (East London).

Bonito, M. (1691): Terra Tremante Overo Continuatione dè Terremoti dalla Creazione del Mondo fino al Tempo Presente (Parrino and Mutii, Naples), pp. 822.

BoyLE, R. (1666): A confirmation of the former account touching the late earthquake near Oxford, and the concomitants thereof, Philos. Trans. R. Soc. London, 1, 179-181.

BrowitT, C.W.A., P.W. Burton and R. Lidster (1976): Seismicity of the Inverness Region, IGS Global Seismol. Un., Rep. No. 76.

(*) BGS reports are available from the BGS Bookshop, Kingsley Dunham Centre, Keyworth, Nottingham, NG12 5GG; or sales@bgs.ac.uk 
Burton, P.W., R.M.W. Musson, and G. Neilson (1984a): Studies of Historical British Earthquakes, BGS Global Seismol., Rep. No. 237.

Burton, P.W., R.M.W. Musson and G. NeIlson (1984b): Macroseismic report on historical British earthquakes IV: Lancashire and Yorkshire, BGS Global Seismol. Rep. No. 219, 2 vols.

BURTON, R. (1734): The general history of earthquakes: being an account of the most remarkable and tremendous earthquakes that have happened in divers parts of the world, from the Creation to this time; as they are recorded by sacred and common authors; and particularly those lately in Naples, Smyrna, Jamaica and Sicily (Bettesworth, London).

ButLer, R. (1849): The Annals of Ireland by Friar John Clyn and Thady Dowling (Irish Archæological Society, Dublin).

Davison, C. (1900): Scales of seismic intensity, Philos. Mag. 5th Ser, 50, 44-53.

Davison, C. (1924): A History of British Earthquakes (CUP, Cambridge).

DollaR, A.T.J. (1950): Catalogue of Scottish Earthquakes, 1916-1949, Trans. Geol. Soc. Glasgow, 21 (2), 283-361.

FLEMING, A. (1580): A bright burning beacon, forewarning all wise virgins to trim their lampes against the coming of the bridegroome, conteining a generall doctrine of sundrie signes and wonders, specially earthquakes both particular and generall: A discourse of the end of this world: A commemoration of our late earthquake, the 6 of April, about 6 of the clocke in the evening 1580 , and a praier for the appealing of Gods wrath and indignation (Denham, London).

GOAD, J. (1686): Astro-Meteorologica (Blagrave, London).

GREY, Z. (1750): A chronological and historical account of the most memorable earthquakes that have happened in the World from the beginning of the Christian period to the present year 1750, with an appendix, containing a distinct series of those that have been felt in England, and a preface, seriously address'd to all Christians of every denomination (Bentham, Cambridge).

GRÜNTHAL, G. (Editor) (1998): European Macroseismic Scale 1998 (EMS-98), in Cahiers du Centre Europèen de Gèodynamique et de Séismologie (Luxembourg), 15, pp. 99.

HoFf, K.E.A. vON (1840): Chronik der Erdbeben und VulkanAusbrüche, I. Theil (Justus, Perthes, Gotha), pp. 470.

HoLINSHED, R. (1577): The firste volume of the chronicles of England, Scotlande, and Irelande, conteyning, the description and chronicles of England, from the first inhabiting vnto the conquest, the description and chronicles of Scotland, from the first originall of the Scottes nation, till the yeare of our Lorde 1571, the description and chronicles of Yrelande, likewise from the firste originall of that Nation, vntill the yeare 1547 (Bishop, London).

Holinshed, R., W. Harrison, StanyHurst, R. and I. HOOKER (Editors) (1587): The first and second volumes of Chronicles: Comprising 1. The description and historie of England, 2. The description and historie of Ireland, 3. The description and historie of Scotland: first collected and published by Raphaell Holinshed, William Harrison, and others; now newlie augmented and continued (with manifold matters of singular note and worthie memorie) to the yeare 1586 by Iohn Hooker alias Vowell Gent. and others; with conuenient tables at the end of these volumes (Denham, London).

KövESLIGETHY, R. DE (1906): A makroszeizmikus rengések feldolgozása, Math. és Természettudományi Értesitõ, 24, 349-368.

LILWALL, R.C. (1976): Seismicity and seismic hazard in Britain, IGS Seismol. Bull., 4 (HMSO, London).

Mallet, R. (1853-1855): Catalogue of recorded earthquakes from 1606 B.C. to A.D. 1850, Brit. Ass. Rep., 1853, 1-176; 1854, 118-212; 1855, 2-236.

Meldola, R. and W. White (1885): Report on the East Anglian earthquake, Essex Field Club Spec. Mem., 1.

MelviLle, C.P. (1985): The geography and intensity of earthquakes in Britain - the eighteenth century, in Earthquake Engineering in Britain (Telford, London).

MelviLle, C.P. (1986): Historical earthquakes in northwest England, Trans. Cumb. West. Ant. Arch. Soc., 86, 193219

Melville, C.P., A. LeVret, P. AlexAndre, J. LAmbert and J. VoGT (1996): Historical seismicity of the Straits of Dover-Pas de Calais, Terra Nova, 8, 626-647.

Milne, D. (1842): Notices of earthquake-shocks felt in Great Britain, and especially in Scotland, with inferences suggested by these notices as to the causes of the shocks, Edinburgh N. Phil. J., 31, 92-122.

Milne, J. (1911): A Catalogue of Destructive Earthquakes A.D. 7 to A.D. 1899, BAAS (London), pp. 92.

Mourant, A.E. (1931). Earthquakes of the Channel Islands and neighbouring countries, Société Jersiaise (St Helier).

Musson, R.M.W. (1986): The use of newspaper data in historical earthquake studies, Disasters, 10 (3), 217-223.

Musson, R.M.W. (1987): Seismicity of Southwest Scotland and Northwest England; with a catalogue of earthquakes within $75 \mathrm{~km}$ of Chapelcross, BGS Global Seismol., Rep. No. 316.

Musson, R.M.W. (1989a): Seismicity of Cornwall and Devon, BGS Global Seismol., Rep. No. WL/89/11.

Musson, R.M.W. (1989b): Seismic hazard assessment for Fort William, BGS Seismol., Rep. No. WL/9/39.

Musson, R.M.W. (1991): Macroseismic effects of the 17 March 1871 Kendal earthquake, BGS Global Seismol. Rep. No. WL/91/17.

Musson, R.M.W. (1993): Discovery of a curious seismological monument from 19th century Scotland, Terra Nova, 5, 513 .

Musson, R.M.W. (1994): A catalogue of British earthquakes, BGS Global Seismol., Rep. No. WL/94/04.

Musson, R.M.W. (1996a): The seismicity of the British Isles, Ann. Geofis., XXXIX (3), 463-469.

Musson, R.M.W. (1996b): Determination of parameters for historical British earthquakes, Ann. Geofis., XXXIX (5), 1041-1048.

Musson, R.M.W. (1996c): Roots and references for the U.K. earthquake catalogue, BGS Global Seismol., Rep. No. WL/96/03.

Musson, R.M.W. (1998): Historical seismicity of the Western Frontiers area, BGS Global Seismol., Rep. No. $W L / 98 / 26$.

Musson, R.M.W. (2002): Historical earthquakes of the British Isles, in International Handbook of Earthquake 
and Engineering Seismology, edited by W.H.K. LEE, H. Kanamori, P.C. Jennings and C. Kisslinger (Academic Press, San Diego).

Musson, R.M.W., G. Neilson, and P.W. Burton (1984a): Macroseismic reports on historical British earthquakes I: Northwest (England and Southwest Scotland), BGS Global Seismol., Rep. No. 207, 2 vols.

Musson, R.M.W., NeIlson, G. and P.W. Burton (1984b) Macroseismic reports on historical British earthquakes II: (North Wales and Irish Sea), BGS Global Seismol., Rep. No. 208

Musson, R.M.W., NeIlson, G. and P.W. Burton (1984c): Macroseismic reports on historical British earthquakes III: (Central and West Scotland), BGS Global Seismol., Rep. No. 209

Musson, R.M.W., G. NeIlson, and P.W. Burton (1984d) Macroseismic reports on historical British earthquakes VII: (North Scotland), BGS Global Seismol., Rep. No. 232.

Musson, R.M.W., G. Neilson, and P.W. Burton (1984e): Macroseismic reports on historical British earthquakes VIII: (South Wales), BGS Global Seismol., Rep. No. 233, 2 vols.

Musson, R.M.W., G. NeILson and P.W. Burton (1984f): Macroseismic reports on historical British earthquakes IX: Dover Straits. BGS Global Seismol., Rep. No. 234.

Musson, R.M.W., G. NeILson and P.W. Burton (1986a): Macroseismic reports on historical British earthquakes XII: 1927 January 24 (North Sea), BGS Global Seismol., Rep. No. 281.

Musson, R.M.W., G. NeILson and P.W. Burton (1986b) Macroseismic reports on historical British earthquakes XIII: 1852 November 9 (Irish Sea), BGS Global Seismol., Rep. No. 283.

Musson, R.M.W. and D.W. Redmayne (1986): Historical earthquakes in the Dunoon area, BGS Global Seismol., Rep. No. 312

Musson, R.M.W., G. NeILson and P.W. Burton (1987) Macroseismic reports on historical British earthquakes X: The Great Glen, BGS Global Seismol., Rep. No. 347.

Musson, R.M.W., G. Neilson and P.W. Burton (1990): Macroseismic reports on historical British earthquake XIV: 22 April 1884 Colchester, BGS Seismol., Rep. No. WL/90/33.

Neilson, G., R.M.W. Musson and P.W. Burton (1984a) The «London» earthquake of 1580 April 6, Eng. Geol. 20, 113-142.

NeILson, G., R.M.W. Musson and P.W. BurTon (1984b) Macroseismic reports on historical British earth- quakes V: Midlands, BGS Global Seismol., Rep. No. 228, 2 vols.

NeILson, G., R.M.W. Musson and P.W. Burton (1984c): Macroseismic reports on historical British earthquakes VI: The South and Southwest of England, BGS Global Seismol., Rep. No. 231.

Neilson, G., R.M.W. Musson and P.W. Burton (1986): Macroseismic reports on historical British earthquakes XI: 1931 Jun 7 North Sea, BGS Global Seismol., Rep. No. 280.

OCKENDEN, R.E. (1936): Thomas Twynès Discourse on the Earthquake of 1580 (Pen-in-Hand Publishing, Oxford).

Ove ARUP (1993): Earthquake Hazard and Risk in the U.K., (Dept. of Environment, London).

Perrey, A. (1849): Sur les tremblements de terre dans les Iles Britanniques, Ann. Sci. Phys. Nat. (Soc. Nat. d'Agr. de Lyon), 2nd series, 1, 115-177.

PrinCIPIA MECHANICA LTD. (1982): British Earthquakes (PML, Cambridge).

ROPER, W. (1889): A list of the More Remarkable Earthquakes in Great Britain and Ireland during the Christian Era (T. Bell, Lancaster).

SHorT, T. (1749): A General Chronological History of the Air, Weather, Seasons, Meteors, etc. (Longman and Miller, London).

Soll Mechanics Ltd. (1982): Reassessment of U.K. Seismicity Data (SML, Bracknell).

Stucchi, M., P. Albini, R. Camassi, R.M.W. Musson and R. TAtevossian, (1999): Main results of the project «BEECD»: a Basic European Earthquake Catalogue and a Database for the evaluation of long-term seismicity and seismic hazard, Rep. to the EC, Project EV5V-CT94-0497.

Tiedemann, H. (1991): Catalogue of Earthquakes and Volcanic Eruptions, (Swiss Re, Zürich).

Tillotson, E. (1974): Earthquakes, explosions and the deep underground structure of the United Kingdom, $J$. Earth Sci., 8, 353-364.

VAN GILS, J.M. (1988): Catalogue of European Earthquakes and an Atlas of European Seismic Maps, CEC Rep. No. EUR 11344 EN

WALKER, A.B. (2000): U.K. earthquake monitoring 1999/2000: BGS seismic monitoring and information service, Eleventh Annual Report, BGS Technical Rep. No. WL/00/03.

WALLIS, J. (1666): A relation concerning the late earthquake neer Oxford; together with some observations of the sealed weatherglass, and the barometer, both upon that phaenomenon, and in general, Philos. Trans. R. Soc. London, 1, 166-171. 